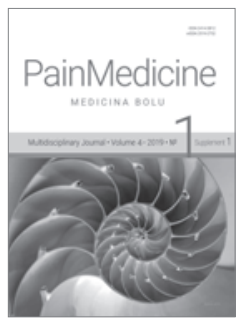

DOI: $10.31636 /$ pmjua.t2.10

\title{
Ранні результати лікування хворих зі спондилоартрозом з використанням пункційних методів
}

\author{
Квасніцький М. В. \\ днУ нПцПКМ дУС, Київ, Україна
}

Актуальність. Висока частота спондилоартрозу та незадовільні результати лікування спонукають до пошуків ефективніших методів лікування цього страждання.

Мета. Визначити ефективність впливу радіочастотної денервації фасеткових суглобів у поєднанні з проведенням епідуральної ін'єкції на ліквідацію больового синдрому у хворих із спондилоартрозом.

Матеріали та методи. Досліджувались дві групи пацієнтів 3 нижньопоперековим больовим синдромом, де провідним клінічним проявом був артроз дуговідросткових суглобів. Основна група склала 108 пацієнтів, яким проводилась радіочастотна денервація фасеткових суглобів у поєднанні 3 епідуральним введенням стероїдних препаратів. Контрольна група - 136 пацієнтів, яким проводилась виключно радіочастотна денервація фасеткових суглобів. Для оцінки больового синдрому використовувалась візуальна аналогова шкала (ВАШ) болю та опитувальник індексу непрацездатності Освестрі. Оцінка проводилась два рази в доопераційному періоді та через три місяці після лікування.

Результати дослідження та їх обговорення. До міні-інвазивного втручання усереднений показник больового синдрому за ВАШ склав 8,3 бала в основній групі та 8,1 бала в контрольній групі. Згідно з результатами лікування в ранньому післяопераційному періоді, усереднений показник больового синдрому склав в основній групі - 2,0 бали, а в контрольній групі - 3,9 бала.

До оперативного втручання усереднений показник функціонального стану пацієнтів за шкалою Освестрі склав 42 бали в основній групі та 44 бали - в контрольній. Згідно 3 результатами лікування в ранньому післяопераційному періоді усереднений показник функціонального стану пацієнтів склав в основній групі 16 балів та в контрольній 28 балів.

Отримані результати дослідження в короткотерміновій перспективі після проведеного лікування свідчать про достовірний результат лікування в обох групах. Встановлена достовірна різниця у ранніх результатах лікування між основною та контрольною групами, як за візуальною аналоговою шкалою болю, так і за шкалою непрацездатності Освестрі на користь методу лікування, де радіочастотна денервація фасеткових суглобів проводилась у поєднанні з епідуральним уведенням стероїдних препаратів.

Висновки. Доведено як ефективність радіочастотної денервації фасеткових суглобів, так і ефективність радіочастотної денервації фасеткових суглобів у поєднанні 3 епідуральним введенням стероїдних препаратів у хворих з нижньопоперековим больовим синдромом, де домінують явища спондилоартрозу. Разом $з$ тим отримано достовірну різницю в ранніх результатах лікування між 
основною та контрольною групами на користь радіочастотної денервації фасеткових суглобів у поєднанні з епідуральним введенням стероїдних препаратів.

Перспективи дослідження. Подальші дослідження дадуть можливість оцінити ефективність лікування спондилоартрозу пункційними методами в довготривалій перспективі.

Ключові слова - спондилоартроз, радіочастотна денервація фасеткових суглобів, епідуральна ін'єкція стероїдних препаратів.

Конфлікт інтересів. Відсутній. 